\title{
MENGENAL JENIS HIU APENDIKS II CITES
}

\author{
Oleh \\ Fahmi $^{1)}$
}

\section{ABSTRACT}

KNOWING SHARKS LISTED IN APPENDIX II CITES. Sharks have become one of major concerns in fisheries management and marine conservation worldwide. Many members of this group are threatened to extinction due to extensive exploitation since few decades ago. Several species of sharks are now listed in the CITES appendices, which controls the international trade for endangered species. Most of them are relatively easy to identify in the field, especially if their fins are still attached. However, few species may difficult to identify correctly due to the similar appearance to other non-CITES species and when the body is not complete anymore. This article aims to give better understanding on how to identify some shark CITES species in detail.

\section{PENDAHULUAN}

Hiu merupakan anggota kelompok ikan bertulang rawan (chondrichthyes), bersama dengan ikan pari dan hiu hantu (holocephalan) (Compagno, 1998; Compagno et al., 2005). Kelompok ikan ini tidak banyak mengalami perubahan secara morfologis dibandingkan dengan nenek moyangnya yang hidup jutaan tahun yang lalu, sehingga ikan hiu dikelompokkan sebagai kelompok ikan fosil hidup (Janvier, 2007).

Berdasarkan karakteristik biologinya, ikan hiu cenderung memiliki laju pertumbuhan yang lambat, berumur panjang, lambat dalam mencapai kematangan seksual dan juga dalam siklus reproduksinya (Bonfil, 1994; Camhi et al., 1998; Stevens et al., 2000; Cavanagh et al., 2003). Selain itu, hiu umumnya bereproduksi secara vivipar (melahirkan anak), sehingga jumlah anak yang dihasilkan oleh satu betina dalam satu siklus reproduksi cenderung sedikit. Umumnya, hiu hanya melahirkan kurang dari 10 anakan (Cortés, 2000; Compagno et al., 2005; Myers \& Worm, 2005; White et al., 2006). Dengan demikian, kelompok ikan hiu relatif rentan terhadap eksploitasi berlebih (overeskploitasi), karena apabila populasinya di alam terganggu, maka akan membutuhkan waktu yang lama untuk kembali pulih (recovery) (Bonfil, 1994; Stevens et al., 2000).

Pemanfaatan hiu sebagai salah satu komoditas perikanan sudah berlangsung sejak berabad-abad yang lalu, namun pemanfaatannya semakin meningkat secara global sejak tahun 1960an, karena tingginya permintaan terhadap produk siripnya dengan harga yang menjanjikan (Bonfil, 1994; Dulvy et al., 2014). Clarke (2007) mengestimasi tingginya tingkat perdagangan sirip di dunia yang

\footnotetext{
$\overline{{ }^{1)} \text { Pusat Penelitian Oseanografi - LIPI }}$
} 
mencapai US\$ 400-500 juta per tahun, namun telah mengorbankan lebih dari 70 juta ekor hiu yang ditangkap setiap tahunnya. Tingginya permintaan sirip hiu menyebabkan populasi hiu menurun secara global sejak tahun 1990an dan populasi beberapa jenis hiu yang bernilai ekonomis tinggi telah mengalami overeksploitasi (Bonfil, 1994; Stevens et al., 2000; Dulvy et al., 2014).

Upaya pengelolaan perikanan hiu untuk memulihkan populasinya di alam telah dilakukan sejak tahun 2000an, baik melaluiupayaFAOdenganmencanangkan IPOA-Sharks (International Plan of Action for the Conservation and Management of Sharks), penerapan NPOA (National Plan of Action) untuk pengelolaan perikanan hiu di setiap negara pemanfaat komoditas hiu, hingga penerapan aturan perdagangan hiu dalam CITES (the Convention on International Trade of Endangered Species) (Fowler \& Cavanagh, 2005; Lack \& Sant, 2011). Sebagai sebuah konvensi internasional yang menangani perdagangan jenis satwa dan tumbuhan yang terancam punah, CITES telah membuat daftar apendiks jenis-jenis satwa dan tumbuhan yang diatur perdagangannya berdasarkan aturan yang disepakati oleh negara-negara anggotanya (www.cites.org/eng/disc/text. php). Beberapa jenis hiu yang bernilai ekonomis dan banyak diperdagangkan di pasar internasional, namun sudah dikategorikan ke dalam daftar jenis yang terancam punah dan hiu mulai dimasukkan ke dalam daftar Apendiks II CITES sejak tahun 2003 (Tabel 1). Jenisjenis hiu yang masuk ke dalam daftar apendiks tersebut merupakan jenis-jenis komoditi yang telah disepakati bersama oleh negara-negara anggota CITES dalam sidang Conference of the Parties $(\mathrm{CoP})$ yang dilaksanakan setiap tiga tahun sekali (www.cites.org/eng/cop/index. php). Artikel ini membahas jenis-jenis hiu CITES dan cara mengidentifikasinya, yang diharapkan dapat mempermudah tenaga pencatat ataupun pihak lain yang ingin meminimalisir kesalahan dalam mengidentifikasi jenis hiu apendiks II CITES. 
Tabel 1. Jenis-jenis hiu yang masuk ke dalam daftar apendiks CITES (www.cites.org/ eng/prog/shark/history.php)

\begin{tabular}{lcc}
\hline \multicolumn{1}{c}{ Spesies } & Apendik & $\begin{array}{c}\text { Tanggal } \\
\text { pemberlakuan }\end{array}$ \\
\hline Cetorhinus maximus (Hiu penjemur) & II & \\
Rhincodon typus (Hiu paus) & 13 September 2000) & 13 Februari 2003 \\
Carcharodon carcharias (Hiu putih) & II & 13 Februari 2003 \\
& II & \\
13 September 2000) & 12 Januari 2005 \\
Lamna nasus (Hiu porbeagle) & II & \\
Carcharinus longimanus (Hiu koboy) & (Apendiks III sejak & 14 September 2014 \\
Sphyrna lewini (Hiu martil) & II & 14 September 2014 \\
II & (Apendiks III sejak & 14 September 2014 \\
$\begin{array}{l}\text { Sphyrna mokarran (Hiu martil besar) } \\
\text { Sphyrna zygaena (Hiu martil halus) }\end{array}$ & II & 14 September 2014 \\
Alopias spp. (Hiu tikus/monyet) & II & 14 September 2014 \\
Carcharhinus falciformis (Hiu & II & 04 Oktober 2017 \\
lanjaman) & II & 04 Oktober 2017 \\
\hline
\end{tabular}

\section{IDENTIFIKASI JENIS HIU DAN PERMASALAHANNYA}

Umumnya, jenis-jenis hiu yang masuk ke dalam apendiks CITES merupakan jenis yang relatif mudah atau dapat diidentifikasi, minimal oleh orang yang telah dapat membedakan kelompok hiu dengan kelompok ikan yang lain. Hal tersebut menjadi salah satu pertimbangan dalam setiap sidang $\mathrm{CoP}$ agar hasil konvensi tersebut dapat dijalankan dan diterapkan oleh setiap negara anggota CITES (Mundy-Taylor \& Crook, 2013). Identifikasi jenis hiu dapat dengan mudah dilakukan apabila dalam kondisi ideal, yaitu jenis yang diidentifikasi tidak tercampur dengan jenis hiu yang lain atau dalam keadaaan yang masih segar dan utuh. Namun, hal tersebut umumnya jarang terjadi terutama dalam perikanan artisanal di Indonesia yang memiliki karakteristik multi-spesies. Tingginya keragaman jenis hiu dan keterbatasan dalam kemampuan 
identifikasi merupakan kendala yang sering dihadapi, terutama oleh tenaga pencatat data perikanan di Indonesia (Fahmi \& Dharmadi, 2013a).

Kendala yang sering dialami oleh tenaga pencatat pendataan hiu di Indonesia, baik di tempat pendaratan ikan, di pasar ataupun lokasi pengolahan dan pengumpul ikan, umumnya adalah ikan tercampur dengan jenis yang lain, tertumpuk-tumpuk, atau sudah tidak dalam kondisi utuh (Gambar 1). Permasalahan lain yang sering dihadapi adalah ikan yang akan diidentifikasi dalam proses pengolahan dan transportasi, sehingga waktu yang tersedia untuk mengidentifikasi dan mencatat sangatlah singkat. Kendala lain yang dihadapi, terutama dalam mengidentifikasi hiu apendiks CITES, adalah sulitnya membedakan produk turunan hiu yang hanya berupa sirip, kulit, tulang atau dagingnya saja. Dalam hal ini, tes DNA perlu dilakukan untuk memastikan bahwa komoditi produk hiu yang diperiksa bukan merupakan bagian tubuh dari jenis hiu apendiks CITES.

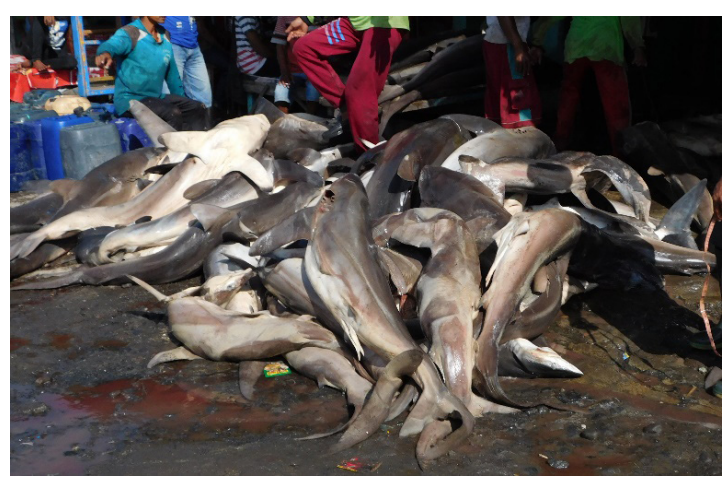

(a)

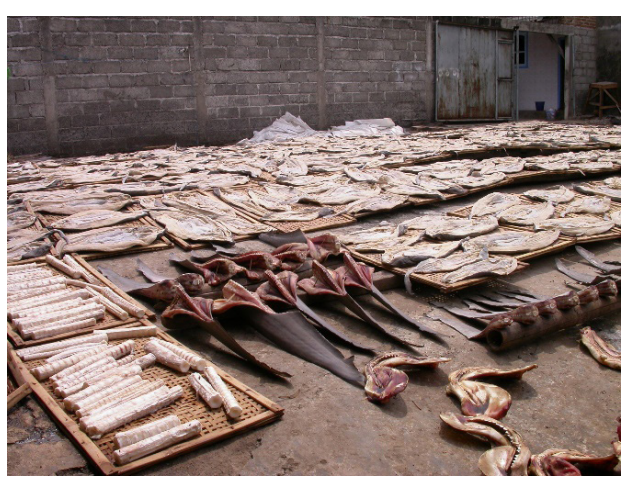

(b)

Gambar 1. Ilustrasi kondisi hiu yang tertumpuk di lokasi pendaratan ikan (a) atau tidak utuh (b), sehingga menyulitkan dalam identifikasi jenis (Foto: koleksi pribadi).

Di lain pihak, seiring dengan berjalannya waktu, makin banyak jenis hiu yang masuk ke dalam daftar apendiks II CITES. Beberapa jenis hiu apendiks II CITES diketahui memiliki tingkat kemiripan yang tinggi dengan jenis hiu nonapendiks II CITES, seperti Carcharodon carcharias, Lamna nasus dan Carcharhinus falciformis. Dalam beberapa tahun ke depan, bukan tidak mungkin akan semakin banyak jenis hiu yang masuk ke dalam daftar apendik CITES yang pada prakteknya akan lebih sulit untuk diidentifikasi.

Beberapa upaya yang dilakukan
untuk meminimalisir kesalahan
identifikasi jenis hiu apendiks CITES
antara lain adalah dengan melakukan
berbagai pelatihan pengenalan jenis hiu
yang telah dilakukan dalam beberapa
tahun terakhir oleh Kementerian Kelautan
dan Perikanan, pengadaan buku-buku


panduan identifikasi hiu (White et al., 2006; Last et al., 2010; Fahmi \& Dharmadi, 2013a), serta penerbitan poster dan spanduk terkait pengenalan jenis hiu apendiks CITES oleh berbagai pihak baik dari kalangan pemerintah, akademisi ataupun lembaga swadaya masyarakat.

\section{PENGENALAN JENIS HIU APENDIK II CITES}

Pada bagian ini, penulis hanya menyampaikan poin-poin penting terkait dengan pengenalan jenis hiu apendiks CITES yang ada dan ditemukan di Indonesia. Beberapa hal yang perlu diketahui antara lain terkait dengan ciri utama (karakter khusus) pada tubuh hiu apendiks CITES yang dapat digunakan untuk membedakan dengan jenis hiu lain, warna tubuh, bentuk sirip dan juga bentuk giginya.

\section{a. Hiu Paus (Rhincodon typus)}

Hiu paus merupakan jenis hiu dan ikan terbesar di dunia. Umumnya panjang tubuh ikan ini dapat mencapai hingga 12 meter, namun kemungkinan juga bisa hingga 18 meter (Compagno, 1984; 1998; White et al., 2006). Ukuran hiu paus yang biasa ditemukan di perairan Indonesia berkisar antara dua hingga tujuh meter, berdasarkan hasil pengamatan terhadap keberadaan hiu paus di Teluk Cenderawasih, Papua dan
Talisayan, Kalimantan Timur (Himawan et al., 2015; Yusma et al., 2016).

Ikan hiu paus sangat mudah dikenali. Selain karena ukurannya yang besar, ikan ini juga memiliki bentuk kepala yang pipih melebar dan mulut yang cukup besar di bagian depan. Tubuhnya tertutup oleh kulit yang tebal dengan gurat-gurat menonjol di sepanjang sisi tubuhnya, dan memiliki corak warna abuabu dengan totol-totol berwarna putih atau kekuningan (White et al., 2006; Fahmi \& Dharmadi, 2013a). Corak totoltotol tersebut terkadang menjadi kendala ketika harus mengidentifikasi potongan tubuhnya seperti bagian sirip. Sirip hiu paus sekilas mirip dengan sirip pari kupukupu (Rhina ancylostoma), karena samasama memiliki warna kelabu dan totoltotol putih. Namun, sebenarnya sirip kedua jenis ini sangat mudah dibedakan, terutama dari ukurannya. Tinggi sirip pari kupu-kupu umumnya berukuran kurang dari $30 \mathrm{~cm}$, sedangkan sirip hiu paus umumnya jauh lebih besar yaitu lebih dari $30 \mathrm{~cm}$. Selain itu, totol-totol pada hiu paus umumnya lebih rapi membentuk garis dan agak memiliki jarak, sedangkan totol-totol pada pari kupu-kupu relatif tidak beraturan dan lebih rapat. Jumlah sirip pari kuku-kupu yang diperjualbelikan juga umumnya hanya terdiri dari tiga buah sirip dalam satu setnya, yaitu dua buah sirip punggung dan satu sirip ekor utuh (Gambar 2). 


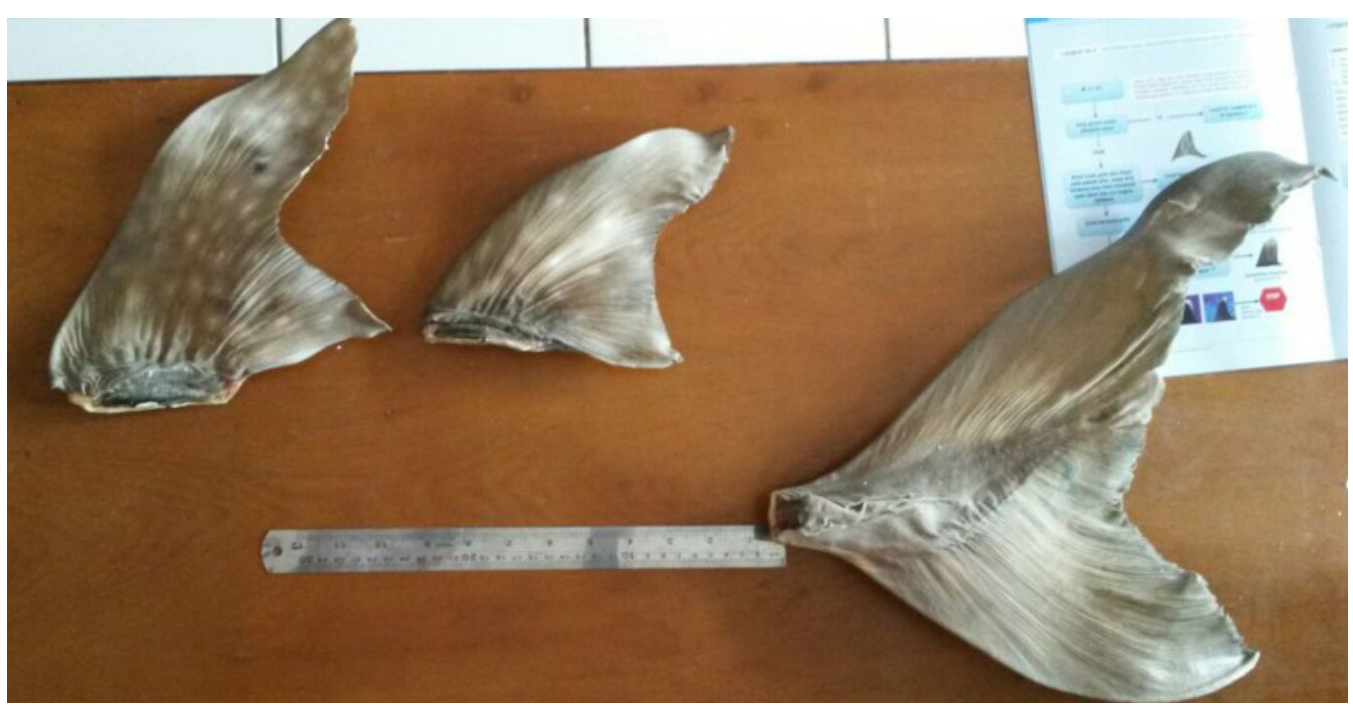

Gambar 2. Sirip dada dan ekor pari kupu-kupu, Rhina ancylostoma. (Foto : koleksi pribadi)

b. Hiu Penjemur (Cetorhinus maximus)

Basking shark atau hiu penjemur sebenarnya sangat jarang ditemukan di perairan Indonesia. Jenis hiu ini pertama kali ditemukan terdampar di pantai Gilimanuk Bali pada bulan Juli 2013 (Fahmi \& White, 2015). Temuan kedua dari jenis ini tercatat pada bulan Oktober 2016, ketika tertangkap di Lamakera, Alor. Cetorhinus maximus merupakan jenis hiu kedua terbesar setelah hiu paus. Panjang tubuh maksimumnya mencapai 9,8 meter namun kemungkinan dapat mencapai hingga 15 meter (Compagno, 2001).
Sama halnya dengan hiu paus, jenis hiu ini juga merupakan pemakan plankton (filter feeder) yang dicirikan dengan bentuk mulutnya yang besar tapi bergigi kecil-kecil. Namun kulit hiu penjemur terlihat tidak setebal kulit hiu paus dan tidak memiliki gurat-gurat serta berwarna kelabu polos. Selain itu, jenis hiu ini juga memiliki celah insang yang relatif sangat besar dibandingkan jenis hiu lainnya (Gambar 3). Ukuran siripnya besar dengan bentuk sirip dada berupa segitiga yang tegak dan tinggi, sedangkan sirip dada berbentuk memanjang dengan ujung yang meruncing. 


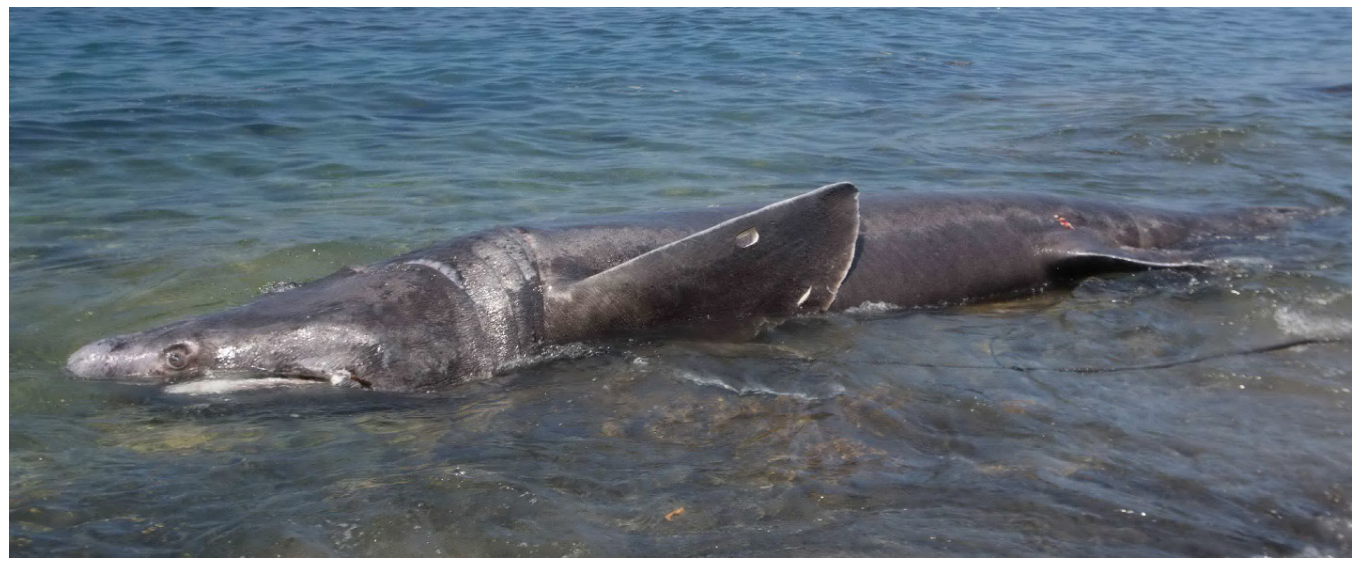

Gambar 3. Hiu penjemur (Cetorhinus maximus) yang ditemukan di Lamakera (Foto kiriman dari W. White).

\section{c. Hiu Putih (Carcharodon carcharias)}

Hiu putih lebih dikenal dengan sebutan great white shark, yang merupakan ikon ikan hiu sebagai pembunuh manusia, karena adanya filmfilm Hollywood yang menyesatkan, seperti Jaws, Shark Night, Shark Attack, Red Water, Deep Blue Sea dan lain sebagainya. Namun dengan adanya filmfilm tersebut, jenis ikan hiu ini menjadi mudah dikenali dan diidentifikasi. Hiu putih termasuk ke dalam kelompok hiu Lamniformes yang memiliki lunas pada pangkal ekornya, yang merupakan ciri utama dari tipe ikan perenang cepat. Ikan hiu tersebut juga merupakan ikan hiu terbesar yang bukan pemakan plankton atau dalam artian merupakan predator sejati. Ukuran tubuhnya dapat mencapai 7,2 meter, namun umumnya ditemukan dengan ukuran maksimum antara lima hingga enam meter (Compagno, 1998; Compagno et al., 2005).

Hiu putih sangat jarang ditemukan di perairan Indonesia, karena sebenarnya jenis hiu ini lebih menyukai hidup di perairan yang dingin dan hanya sesekali terlihat di perairan tropis (Taylor, 1985; Cliff et al., 2000; Compagno, 2001). Hiu putih pertama kali tercatat didaratkan di tempat pendaratan ikan Tanjungluar Lombok pada Bulan Juli 2013 dengan ukuran tubuh diperkirakan mencapai enam meter (Fahmi \& Dharmadi, 2014). Karena besarnya, tubuhnya dipotong hingga lima bagian agar dapat mudah diangkat dan dibawa ke tempat pelelangan ikan. Jenis hiu ini juga pernah terlihat di perairan Sabah, Malaysia pada tahun 1981 (Duffy, 2016).

Bagian tubuh hiu putih dapat diidentifikasi terutama dari ukurannya yang relatif lebih besar dari jenis hiu lainnya. Bentuk sirip punggungnya segitiga tegak dengan ujung meruncing, sama halnya dengan bagian sirip dadanya (Gambar 4c,d). Sedangkan giginya juga sering dijadikan aksesoris karena bentuknya yang segitiga hampir simetris dan relatif besar (Gambar 4d). 

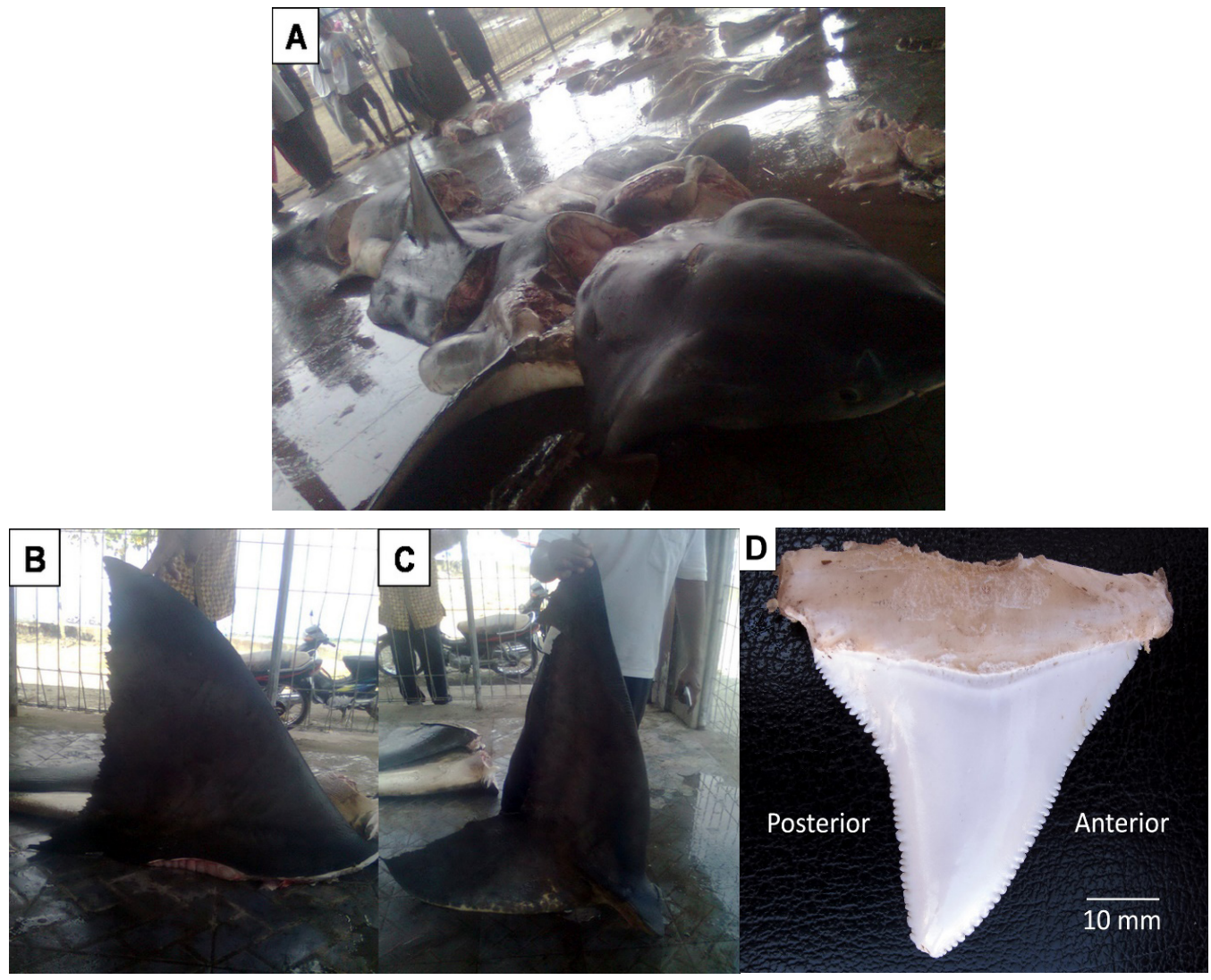

Gambar 4. Hiu putih yang didaratkan di Tanjungluar Lombok tahun 2013 (Fahmi \& Dharmadi, 2014).

d. Hiu Koboy (Carcharinus longimanus)

Hiu koboy merupakan jenis hiu oseanik yang umumnya ditemukan di perairan lepas pantai (Compagno, 1998; White et al., 2006). Hiu ini mudah dikenali karena bentuk ujung siripnya yang membulat dan berwarna putih, terutama pada bagian sirip punggung, dada dan ujung ekornya (White et al., 2006). Namun, untuk anakan (juvenile) hiu koboy, warna putih pada ujung siripnya kadang belum nampak dan terkadang juga terdapat warna hitam pada ujung siripnya (Gambar 5). 


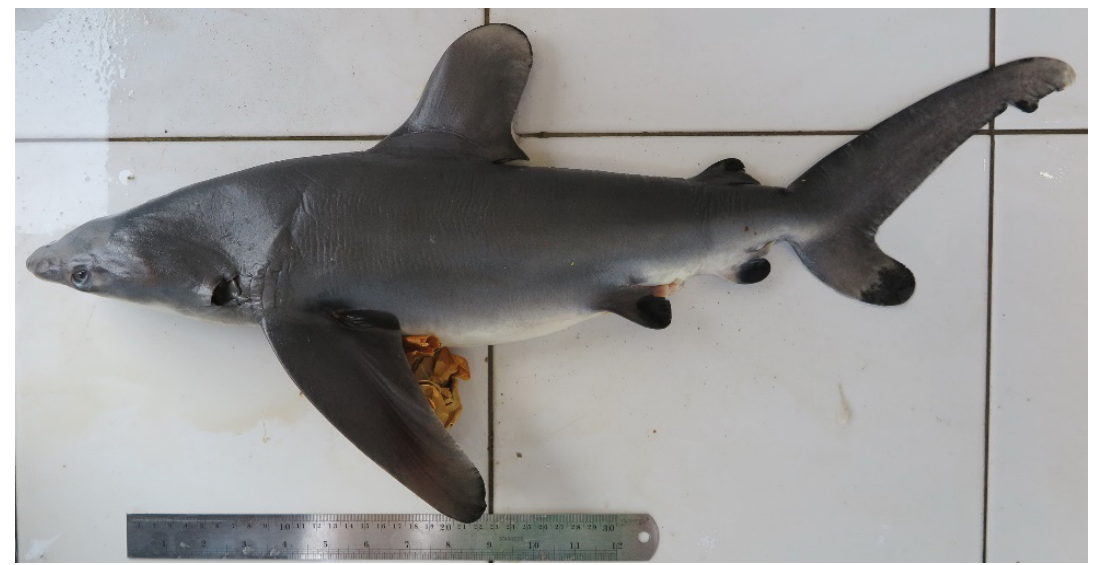

Gambar 5. Anakan hiu koboy (Carcharinus longimanus) (Foto: koleksi pribadi).

e. Hiu martil (Sphyrna spp.)

Hiu martil merupakan jenis hiu yang paling mudah dikenali apabila masih dalam kondisi utuh, karena bentuk kepalanya yang sangat khas, yaitu pipih dan berbentuk seperti kepala martil. Tiga jenis hiu martil yang masuk ke dalam daftar Apendiks II CITES dapat dibedakan dari bentuk ujung kepalanya. Hiu martil jenis Sphyrna lewini, yang merupakan jenis yang paling umum ditemukan di Indonesia, dikenali dengan bentuk ujung kepala yang sedikit melengkung dengan adanya lekukan di bagian tengahnya, dan sisi samping di belakang mata berbentuk cekung (Gambar 6a). Sedangkan hiu martil besar ( $S$. mokarran) memiliki ujung kepala yang relatif rata dengan sedikit lekukan di tengahnya, dan bagian sisi samping di belakang mata terlihat relatif lurus (Gambar 6b). Di lain pihak, hiu martil halus (S. zygaena) memiliki bentuk ujung kepala yang melengkung tanpa ada lekukan di bagian tengahnya, sedangkan bagian sisi samping di belakang mata terlihat melengkung ke belakang (Gambar 6c).
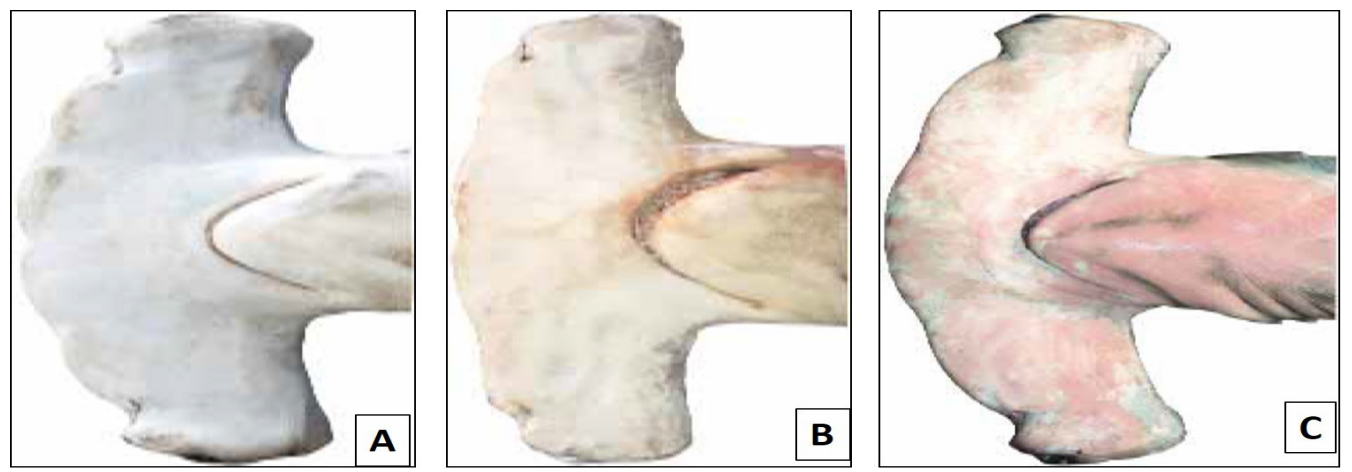

Gambar 6. Bentuk kepala hiu martil Sphyrna lewini (a), S. mokarran (b) dan S. zygaena (c) (White et al., 2006). 
Permasalahan yang sering terjadi adalah ketika jenis hiu martil ditemukan dalam kondisi yang tidak utuh. Prosedur yang paling baku dalam mengidentifikasi sirip hiu martil adalah dengan mengidentifikasi sirip punggungnya. Sirip punggung dapat dibedakan dengan sirip dada dengan melihat kedua bagian sisinya. Warna sirip punggung pada kedua sisi siripnya sama, sedangkan sirip dada memiliki warna yang berlainan. Bagian atas sirip dada berwarna serupa dengan warna kulit tubuhnya yang lain, namun bagian bawahnya relatif berwarna putih (cerah). Sedangkan untuk membedakan sirip dada dengan sirip ekor dengan melihat potongan di bagian dasar siripnya. Bagian dasar sirip punggung memiliki potongan yang tidak mencapai ujung, karena ada bagian belakang siripnya yang tidak menempel pada tubuh, sedangkan potongan dasar sirip ekor terlihat terpotong dari depan hingga ke belakang (Abercrombie et al., 2013). Sirip punggung hiu martil dapat dibedakan dengan sirip hiu lainnya dengan mengukur tinggi sirip dari sisi depannya hingga ke ujung atas sirip (OA), kemudian mengukur lebar sirip pada posisi setengah tinggi sirip punggung (W). Hasil pengukuran kemudian dikalkulasi dengan rumus: $(\mathrm{O}-\mathrm{A}) / \mathrm{W}$, apabila hasilnya lebih dari 2,5, maka dapat disimpulkan bahwa sirip tersebut kemungkinan besar adalah sirip hiu martil (Gambar 7). Untuk lebih meyakinkan bahwa sirip yang diidentifikasi tersebut adalah sirip hiu martil, selain melakukan perhitungan di atas, perlu dilihat warna siripnya dan bentuk susunan tulang pada dasar siripnya (Abercrombie et al., 2013). Warna sirip hiu martil cenderung kecoklatan dibandingkan dengan sirip hiu pada umumnya yang relatif berwarna kelabu. Sedangkan susunan tulang sirip punggung hiu martil terlihat rapat dengan lapisan otot yang tipis (Gambar 7b).

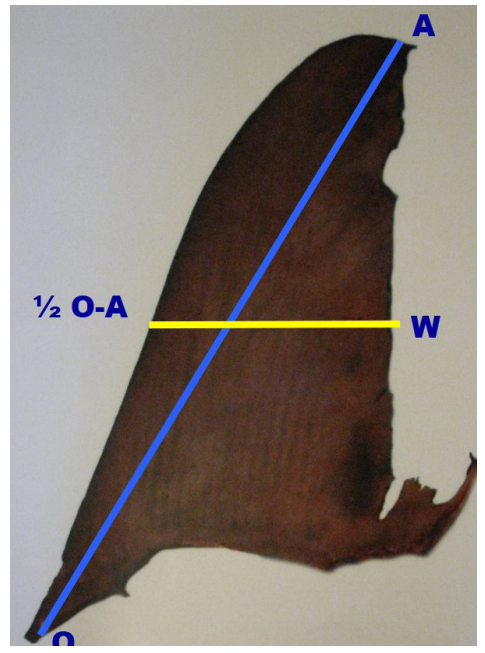

(a)

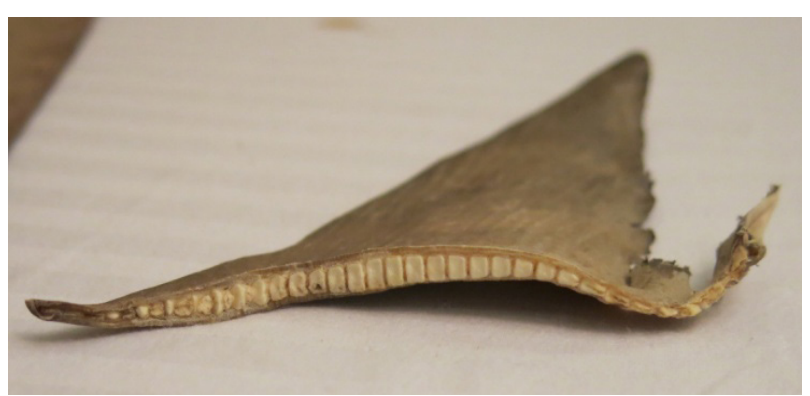

(b)

Gambar 7. Sirip punggung hiu martil (a) dan penampang bagian dasar siripnya (b) (Foto: koleksi pribadi). 


\section{f. Hiu tikus (Alopias spp.)}

Hiu tikus atau hiu monyet (Alopias spp.) merupakan kelompok hiu berekor panjang yang hidup di perairan paparan benua hingga oseanik (White et al., 2006). Dari tiga jenis hiu Marga Alopias yang ada di dunia, dua antaranya ditemukan di Indonesia, yaitu Alopias pelagicus dan A. superciliosus (White et al., 2006; Fahmi \& Dharmadi, 2013b). Kedua jenis ini mudah dikenali apabila dalam keadaan utuh karena memiliki ekor yang hampir sama panjang dengan panjang tubuhnya. Alopias superciliosus dibedakan dengan A. pelagicus dari bentuk matanya yang lebih besar, terdapat gurat atau lekukan yang dalam di bagian tengkuknya (belakang mata), serta memiliki warna tubuh yang lebih gelap (White et al.,
2006; Fahmi \& Dharmadi, 2013a).

Sirip Alopias pelagicus secara umum dapat dibedakan dengan sirip hiu lainnya terutama dari bentuk sirip dadanya yang memanjang dengan ujung yang membulat tajam; sirip punggung tegak; sirip ekor bagian bawah terlihat tegak dan cukup simetris; serta memiliki sirip perut yang besar, hampir menyamai sirip punggungya (Gambar 8). Sirip $A$. superciliosus dapat dibedakan dengan A. pelagicus pada bentuk sirip dada dan punggungnya yang sedikit lebih melengkung ke belakang. Warna sirip hiu Alopias cenderung lebih gelap dibandingkan dengan hiu dari Marga Carcharhinus, dalam bentuk keringnya biasanya ditemukan berwarna kelabu gelap atau kehitaman.

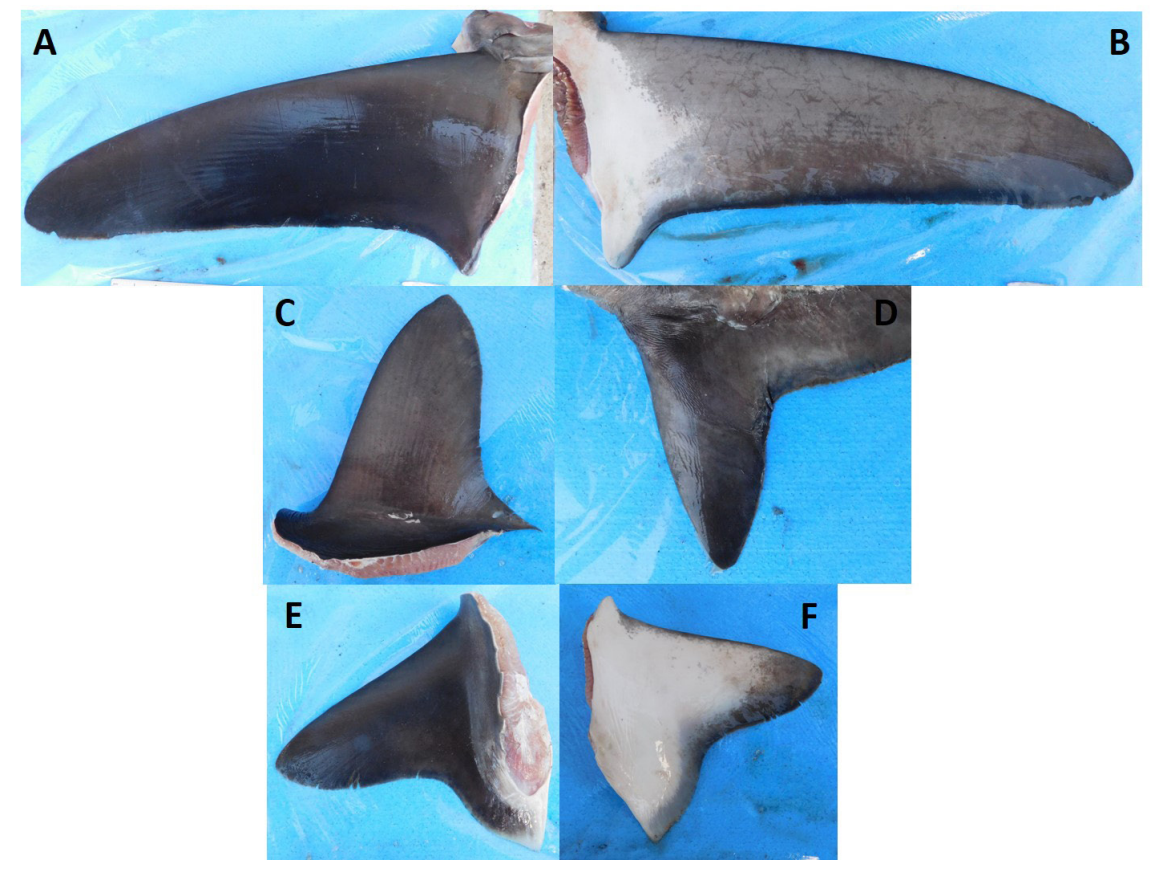

Gambar 8. Sirip Alopias pelagicus: a) sirip dada bagian atas; b) sirip dada bagian bawah; c) sirip punggung; d) sirip ekor bagian bawah; e) sirip perut bagian atas; dan f) sirip perut bagian bawah (Foto: koleksi pribadi). 
g. Hiu lanjaman (Carcharhinus falciformis)

Carcharhinus

falciformis

merupakan salah jenis hiu yang paling umum tertangkap di perairan Indonesia, baik sebagai hasil tangkapan sampingan maupun sebagai target tangkapan (Fahmi \& Dharmadi, 2013b). Di Indonesia, penyebutan hiu lanjaman sebenarnya tidak hanya ditujukan pada jenis $C$. falciformis semata. Karena tingkat kemiripannya yang tinggi, setidaknya ada sembilan jenis hiu dari Marga Carcharhinus yang disebut sebagai hiu lanjaman (Fahmi \& Dharmadi, 2013a). Hal ini dapat menyebabkan permasalahan yang cukup serius terkait pendataan perikanannya, terlebih karena C. falciformis sudah masuk ke dalam daftar apendiks II CITES. Sebagai salah satu persyaratan pengelolaan hiu apendik CITES, pendataan dalam perikanan dan perdagangannya harus tercatat hingga tingkat spesies.

Secara umum, Carcharhinus falciformis dapat diidentifikasi dan dibedakan dengan jenis hiu Carcharhinus lainnya dengan melihat karakteristik utamanya seperti adanya gurat di antara

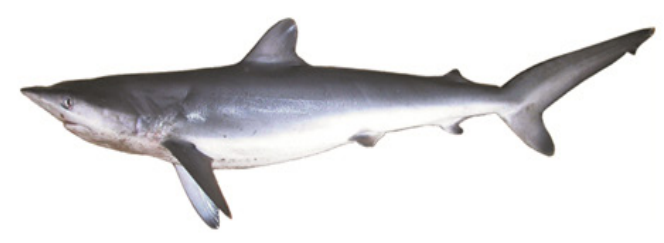

(a) sirip punggung; ujung sirip punggungnya tidak lancip; posisi awal sirip punggung berada di belakang bagian belakang sirip dada; bagian belakang sirip punggung keduanya memanjang; serta memiliki moncong berbentuk parabolik dengan panjang yang moderat (White et al., 2006; Fahmi \& Dharmadi, 2013a). Permasalahannya, yang sering terjadi di lapangan adalah adanya jenis hiu lain yang memiliki karakteristik hampir serupa dengan C. falciformis, yaitu pada jenis C. obscurus (Gambar 9). Jenis ini juga memiliki ciri-ciri yang serupa seperti memiliki gurat punggung; awal sirip punggung tepat di belakang sirip dada; serta bagian belakang sirip punggung kedua yang memanjang (White et al., 2006; Fahmi \& Dharmadi, 2013a). Perbedaaan di antara kedua jenis ini antara lain adalah C. obscurus memiliki ukuran tubuh yang lebih besar (dapat mencapai panjang hingga empat meter); memiliki moncong yang relatif lebih pendek dengan ujung yang membulat; sirip dada lebih melengkung dengan ujung yang lebih lancip, serta memiliki bentuk gigi bagian atas yang lebih lebar (Gambar 10).

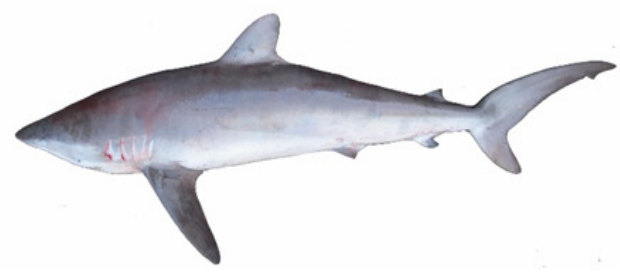

(b)

Gambar 9. Morfologi Carcharhinus falciformis (a) dan Carcharhinus obscurus (b) (Fahmi \& Dharmadi, 2013a). 


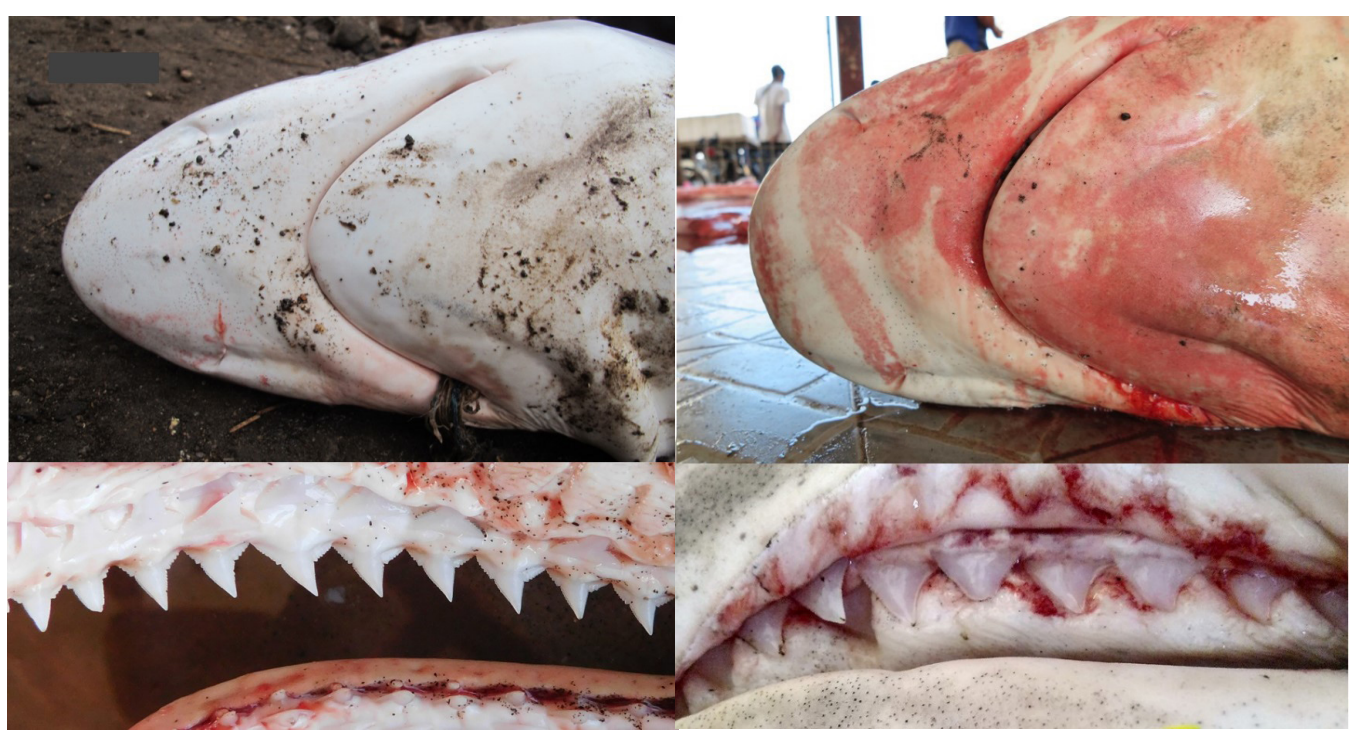

(a)

(b)

Gambar 10. Perbedaan bentuk moncong dan gigi antara Carcharhinus falciformis (a) dan Carcharhinus obscurus (b) (Foto: koleksi pribadi).

Dengan demikian, identifikasi jenis hiu Carcharhinus falciformis memerlukan tingkat ketelitian yang tinggi, terutama apabila melakukan pendataan ketika kedua jenis hiu tersebut ditemukan secara bersamaan, seperti di daerah perairan Samudera Hindia. Patokan lain yang dapat dilihat adalah pada perkembangan klasper untuk individu jantannya. Pada ukuran panjang tubuh sekitar dua meter, klasper $C$. falciformis sudah terlihat panjang dan matang, sedangkan pada jenis C. obscurus masih pendek dan belum matang. Carcharhinus obscurus jantan mencapai matang kelamin pada ukuran panjang total antara 2,8 hingga 3 $\mathrm{m}$ (White et al., 2006).

Bentuk sirip hiu Carcharhinus falciformis relatif mudah diidentifikasi berdasarkan bentuk sirip punggungnya (Gambar 11). Bentuk sirip punggung agak membulat di bagian ujungnya serta sedikit condong ke belakang, dengan bagian belakang yang tidak menempel pada tubuh (free rear tip) terlihat memanjang. Warna sirip bervariasi mulai dari abu-abu hingga abu kecoklatan (Abercrombie et al., 2013). 


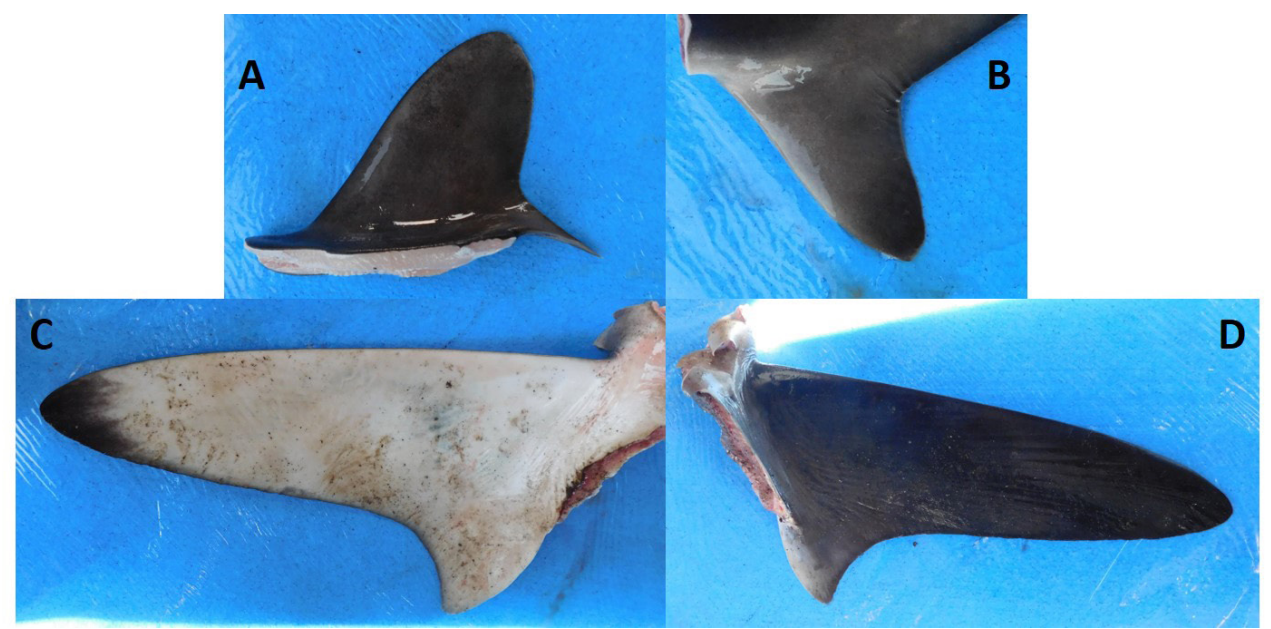

Gambar 11. Bentuk sirip Carcharhinus falciformis: a) punggung; b) ekor; c) dada bagian bawah; d) dada bagian atas (Foto: koleksi pribadi).

\section{PENUTUP}

Ketersediaan buku dan panduan pengenalan jenis hiu apendiks CITES merupakan salah satu upaya pemerintah Indonesia sebagai negara anggota CITES untuk melaksanakan ketentuan-ketentuan yang sudah ditetapkan dalam sidang CoP CITES. Dengan tersedianya panduanpanduan tersebut, diharapkan dapat mempermudah identifikasi produk dan proses pendataan komoditas hiu CITES di pasaran.

\section{DAFTAR PUSTAKA}

Abercrombie, D. L., D. D. Chapman, S. J. B. Gulak and J.K.Carlson. 2013. Visual identification on fins from common elasmobranchs in the Northwest Atlantic Ocean. National Marine Fisheries Service NOAA, Panama City: $51 \mathrm{pp}$.
Bonfil, R. 1994. Overview of world elasmobranch fisheries. FAO, Rome: 119 pp.

Camhi, M. S., S. Fowler, J. Musick, A. Brautigam and S. Fordham. 1998. Sharks and Their Relatives - Ecology and Conservation. IUCN SSC Shark Specialist Group, Gland, Switzerland and Cambridge, $\mathrm{UK}$ : iv $+39 \mathrm{pp}$.

Cavanagh, R. D., P. M. Kyne, S. L. Fowler, J. A. Musick and M. B. Bennett. 2003. The conservation status of Australasian chondrichthyans: Report of the IUCN Shark Specialist Group Australia and Oceania regional Red List workshop, Queensland, Australia In: Cavanagh, R. D., P. M. Kyne, S. L. Fowler, J. A. Musick and M. B. Bennett (Eds.). The University of Queensland, School of Biomedical Sciences, 170 pp. 
Clarke, S. C., E. J. Milner-Gulland and T. Bjørndal. 2007. Perspective: social, economic and regulatory drivers ofthe shark fin trade. Marine Resource Economics 22: 305-327.

Cliff, G., L. J. V. Compagno, M. J. Smale, R. P. Van Der Elst and S. P. Wintner. 2000. First records of white sharks Carcharodon carcharias, from Mauritius, Zanzibar, Madagascar and Kenya. South African Journal of Science 96: 365-367.

Compagno, L. J. V. 1984. FAO species catalogue. Sharks of the world. An annotated and illustrated catalogue of sharks species known to date. Part 1: Hexancathiformes to Lamniformes (Vol. 4). FAO, Rome: 1-249 pp.

Compagno, L. J. V. 1998. Sharks. In: K. E. Carpenter and V. H. Niem (Eds), Species identification guide for fishery purposes. The living marine resources of the western central Pacific. Cephalopods, crustaceans, holothurians and sharks (Vol. 2). FAO, Rome, pp. 1193-1366.

Compagno, L. J. V. 2001. Species catalogue for fishery purpose. Sharks of the world an annotated and illustrated catalogue of sharks species known to date. Bullhead, mackerel and carpet sharks (Heterodontiformes, Lamniformes

and
Orectolobiformes) (Vol. 2). FAO, Rome: 269 pp.

Compagno, L. J. V., M. Dando and S. L. Fowler. 2005. Sharks of the world. Princeton University Press, New Jersey: 368 pp.

Cortés, E. 2000. Life History Patterns and Correlations in Sharks. Reviews in Fisheries Science, 8 (4): 299344.

Duffy, C. A. J. 2016. First record of the white shark Carcharodon carcharias (Lamniformes: Lamnidae) from Sabah, Malaysian Borneo. Marine Biodiversity Records, 9 (1).

Dulvy, N. K., S. L. Fowler, J. A. Musick, R. D. Cavanagh, P. M. Kyne, L. R. Harrison, J. K. Carlson, L. N. Davidson, S. V. Fordham, M. P. Francis, C. M. Pollock, C. A. Simpfendorfer, G. H. Burgess, K. E. Carpenter, L. J. Compagno, D. A. Ebert, C. Gibson, M. R. Heupel, S. R. Livingstone, J. C. Sanciangco, J. D. Stevens, S. Valenti and W. T. White. 2014. Extinction risk and conservation of the world's sharks and rays. eLife, 3, e00590.

Fahmi dan Dharmadi. 2013a. Pengenalan jenis-jenis hiu Indonesia. Direktorat Konservasi Kawasan dan Jenis Ikan, Kementerian Kelautan dan Perikanan, Jakarta: 63 pp. 
Fahmi dan Dharmadi. 2013b. Tinjauan status perikanan hiu dan upaya konservasinya di Indonesia. Direktorat Konservasi Kawasan dan Jenis Ikan, Kementrian Kelautan dan Perikanan, Jakarta: 179 pp.

Fahmi and Dharmadi. 2014. First confirmed record of the white shark Carcharodon carcharias (Lamniformes: Lamnidae) from Indonesia. Marine Biodiversity Records, 7.

Fahmi and W. T. White. 2015. First record of the basking shark Cetorhinus maximus (Lamniformes: Cetorhinidae) in Indonesia. Marine Biodiversity Records, 8 (e18): 1-3.

Fowler, S. L. and R. D. Cavanagh. 2005. International conservation and management initiatives for chondrichthyan fish. In Sharks, rays and chimaeras: The status of the chondrichthyan fishes. IUCN / SSC Shark Specialist Group, Gland, Switzerland and Cambridge, UK, pp. 58-69.

Himawan, M. R., C. Tania, B. A. Noor, A. Wijonarno, B. Subhan and H. Madduppa. 2015. Sex and size range composition of whale shark (Rhincodon typus) and their sighting behaviour in relation with fishermen lift-net within Cenderawasih Bay National Park, Indonesia. AACL Bioflux, 8 (2): 123-133.
Janvier, P. 2007. Living primitive fishes and fishes from deep time. In: D. J. Mckenzie, A. P. Farrell and C. J. Brauner (Eds), Primitive fishes. Elsevier Academi Press, California, USA, pp. 2-53.

Lack, M. and G. Sant. 2011. The future of sharks: a review of action and inaction. TRAFFIC International \& The PEW Environment Group, Cambridge, UK

Last, P. R., W. T. White, J. N. Caira, Dharmadi, Fahmi, K. Jensen, A. P. K. Lim, B. M. Manjaji, G. J. Naylor, J. J. Pogonoski, J. D. Stevens and G. K. Yearsley. 2010. Sharks and Rays of Borneo. CSIRO, Collingwood, Australia: 298 pp.

Mundy-Taylor, V. and V. Crook. 2013. Into the deep: Implementing CITES measures for commerciallyvaluable sharks and manta rays. Traffic: $106 \mathrm{pp}$.

Myers, R. A. and B. Worm. 2005. Extinction, survival or recovery of large predatory fishes. Philosophical Transactions of the Royal Society B, 360 (1453): 13-20.

Stevens, J. D., R. Bonfil, N. K. Dulvy and P. A. Walker. 2000. The effects of fishing on sharks, rays, and chimaeras (chondrichthyans), and the implications for marine ecosystems. ICES Journal of Marine Science, 57 (3): 476-494. 
Taylor, L. 1985. White sharks in Hawaii: Historical and contemporary records. Memoirs of the Southern California Academy of Sciences, 9: 41-48.

White, W. T., P. R. Last, J. D. Stevens, G. K. Yearsley, Fahmi and Dharmadi. 2006. Economically important sharks and rays of Indonesia. ACIAR, Canberra: $329 \mathrm{pp}$.
Yusma, A. M. I., C. Tania, R. S. J. Junaidi, Adnan dan L. Otolua. 2016. Identifikasi Kemunculan Hiu Paus (Rhincodon typus) di Perairan Talisayan, Kabupaten Berau, Provinsi Kalimantan Timur. Dalam: Dharmadi and Fahmi (Eds), Simposium hiu dan pari di Indonesia. WWF, Bogor, pp. 107-113. 